\title{
EVALUATION OF OCULAR PROSTHESIS BIOFILM AND ANOPHTHALMIC CAVITY CONTAMINATION AFTER USE OF THREE CLEANSING SOLUTIONS
}

\author{
Regina Márcia Zuccolotto Felippe PARANHOS ${ }^{1}$, Carlos Henrique BATALHÃO ${ }^{2}$, Marisa SEMPRINI ${ }^{3}$, \\ Simone Cecílio Hallak REGALO ${ }^{3}$, Izabel Yoko ITO ${ }^{4}$, Maria da Glória Chiarello de MATTOS ${ }^{5}$
}

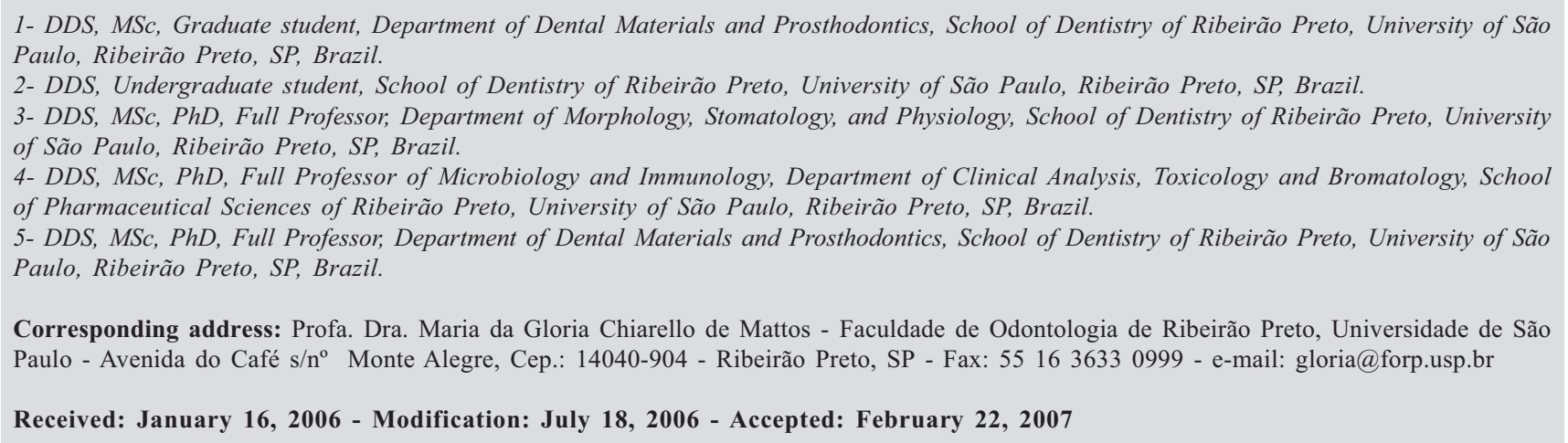

\begin{abstract}
$I_{\mathrm{n}}$ bacteria due to the superficial characteristics of the prosthesis' material, use of inadequate cleansing solutions and methods, or because the void located between the internal portion of the prosthesis and the anophthalmic cavity (AC) mucosa. Objective: The aim of this study was to evaluate OP biofilm formation and the level of contamination of the internal portion of the OP and the AC in 24 patients. Material and Methods: Material was collected from the AC at the beginning of the study and 15 days after cleansing of the OP with 3 cleansing solutions: a neutral liquid soap, a multiuse solution for contact lens (Complete) and $0.12 \%$ chlorhexidine (Periogard). The collected materials were sowed in Petri dishes containing selective media for aerobic and facultative microorganisms, specifically staphylococci (Hipersalt agar with egg yolk), aerobic microorganisms (Brain Heart Infusion Blood Agar), streptococci (Mitis salivarius Agar), gram-negative bacilli (MacConkey Agar) and yeasts (Chromagar Candida ${ }^{\mathrm{TM}}$ ), incubated at $35^{\circ} \mathrm{C}$ or $37^{\circ} \mathrm{C}$ and the number of colony forming units were counted. Data were analyzed statistically by ANOVA, Friedman's test and Spearman's correlation. Results: Aerobic microorganisms, gram-negative bacilli and S. aureus were found in the OP biofilm and in the AC. There was statistically significant difference $(\mathrm{p}<0.05)$ between the number of microorganisms before and after the use of the cleansing solutions. Conclusion: There was positive correlation with respect to the microorganisms present in the OP biofilm and AC for the 4 proposed treatments, indicating that the decrease of OP contamination leads to AC contamination as well.
\end{abstract}

Uniterms: Artificial eye; Eye infections; Prosthesis-related infections.

\section{INTRODUCTION}

Ocular prosthesis (OP) is an artificial replacement for the bulb of the eye and has the goal of reestablishing facial esthetics while maintaining the form of the anophthalmic cavity (AC), preserving the palpebral muscle tone, inhibiting palpebral collapse, directing tear drainage, preventing fluid accumulation in the socket and aiding the patient's social contact ${ }^{7}$.

OP wearers are preset to infections, inflammations and traumas related to physiological and morphological modifications of the AC; AC colonization by pathogenic microbiota; impaired mobility to inadequate prosthesis installation; neglected prosthesis cleansing without removal from the socket for months or years and no washing; and accumulation of secretion, which may cause giant papillary conjunctivitis and consequent intolerance to prosthesis use $^{6,9,10,12-14}$.

The aims of this study were to assess the levels of contamination of OP biofilm and $\mathrm{AC}$ in $\mathrm{OP}$ wearers by counting the number of colony forming units (cfu) before and after use of different cleansing solutions, and to correlate the contamination levels of the AC with those of the OP. 


\section{MATERIALAND METHODS}

Twenty-four OP wearers of both genders with mean age of 44 years were selected from the Rehabilitation Service for Patients with Mutilations of the Face, Head and Neck Regions of the Department of Dental Materials and Prosthodontics (FORP/USP) and followed-up during a 45 day period. Patients attended four visits $(0,15,30$ and 45 days), in which biofilm was collected from the internal surface of the OP as well as from the AC. For collection of material on day 0 (I - Initial), patients did not receive any hygiene instruction. After collection, the patients received cleansing solutions for the OP and were oriented how to clean it 4 times a day, during 15 days. The first solution used, after the initial material collection, was a neutral liquid soap (LS) (Daterra, Ribeirão Preto, São Paulo, Brazil). The patients were instructed to put the LS on their clean hand palms and dab it on the prosthesis for 1 minute, rinsing in running water thereafter. The second solution used was a multiuse solution (MS) for cleansing of contact lenses (Complete, Allergan, Guarulhos, São Paulo, Brazil) and the third was a $0.12 \%$ chlorhexidine solution [Periogard $(\mathrm{P})$, Colgate, São Paulo, SP, Brazil]. The cleansing instructions were similar to those given to LS, except for the fact that MS was not rinsed after application, according to the manufacturer's instructions. Material was collected from the $\mathrm{OP}$ and $\mathrm{AC}$ after 15 days of use of each solution. After the last solution was used for 15 days, the patients attended the fourth appointment and the final collections were performed.

In preparation for material collection, the patients were instructed to wash their hands (water and soap) and the antisepsis was made with a $68 \%$ alcohol gel. The OP was removed by the patient, placed in a sterile Petri dish $(20 \times 100 \mathrm{~mm})$ and taken to an aseptic zone (obtained by 2 alcohol lamps). Collection of the AC material and the biofilm from the internal portion of the OP was done by a single operator with a sterile swab (DME - Diagnósticos Microbiológicos Especializados, Araçatuba, São Paulo, Brazil), maintaining the same frequency of movements during 5 minutes. Still in the aseptic zone, the swab was introduced into a test tube containing $2.0 \mathrm{~mL}$ of Letheen Broth - Calet (Difco, Detroit, Michigan, USA) and was forwarded to the laboratory packed in ice-filled polystyrene boxes to ensure an adequate conservation.

Thereafter, the OPs were polished with pumice (Vigodent, Rio de Janeiro, RJ, Brazil) and Kaolin (ARJ Chemical do Brazil Ltda, Rio de Janeiro, RJ, Brazil), washed with water and soap, rinsed in running tap water and given back to the patients.

The collected material was agitated for 1 minute in a shaker (Mixtron Toptronix, São Paulo, SP, Brazil) and submitted to decimal dilution up to $10^{-4}$. These suspensions were dropped in equidistant points on the Petri dish in a volume of $50 \mu \mathrm{L}$, according to Westergren and Krasse ${ }^{15}$ (1979) onto MacConkey Agar (Mc; Difco, Detroit, Michigan, USA), Chromagar Candida ${ }^{\mathrm{TM}}$ (Cm; CHROMagar, Paris, France), Brain Heart Infusion Blood Agar (As; Difco, Detroit,
Michigan, USA), Hipersalt Agar with egg yolk (Ni) according to Ito, et al. ${ }^{5}$ (1979) and Mitis salivarius Agar (Ms; Difco, Detroit, Michigan, USA).

About $4.0 \mathrm{~mL}$ of thioglycollate medium without dextrose or indicator (Tio's; Difco, Detroit, Michigan, USA) were added to the remaining material and incubated at $37^{\circ} \mathrm{C}$ for 10 days for detection of less than 20 microorganisms.

$\mathrm{Mc}, \mathrm{As}$, and Ni media were incubated at $37^{\circ} \mathrm{C}$ for 24 to 48 hours, while $\mathrm{Cm}$ medium was incubated at $35^{\circ} \mathrm{C}$ for 48 to 72 hours. Ms medium was incubated at $37^{\circ} \mathrm{C}$ for 24 to 96 hours under capnophilic conditions by the candle jar system. After incubation, the material was examined with a stereomicroscope (Nikon, Tokyo, Japan) under reflected light and the number of colony forming units (cfu) was counted.

Data were analyzed statistically by analysis of variance, Friedman's test and Spearman's correlation. Significance level was set at $5 \%$.

\section{RESULTS}

Aerobic microorganisms, $S$. aureus and gram-negative bacilli were detected in the OP biofilm and in the AC (Table 1 and 2).

The statistical results of ANOVA for aerobic microorganisms are shown on Table 3 while the statistical results of Friedman's test for $S$. aureus and gram-negative bacilli are shown on Table 4 . The analysis of the results showed that the initial condition (I) was statistically different from the use of the cleansing solutions (LS, MS, and P) $(p<0.05)$. The results of the Spearman's correlation for the microorganisms present in the OP biofilm and AC for the 4 proposed treatments (I, LS, MS, and P) (Table 5) showed a positive correlation, indicating that as the number of microorganisms on OP surface increased, the number of microorganisms in the AC increased accordingly, in any of the tested conditions. The inverse also occurred. A numerical comparison was made and confirmed this correlation (Table $6)$.

\section{DISCUSSION}

In the present study, the varied microbiota observed in the OP biofilm (aerobic microorganisms, gram-negative bacilli and Staphylococcus aureus) as well as the presence of these microorganisms in the $\mathrm{AC}$ are results consistent with the literature $\mathrm{e}^{1-3,6,9,10,12,13}$.

OP wearers may present a pathogen microbiota in the $\mathrm{AC}$, mainly those who neglect the cleansing of prosthesis, not removing them for days, months or even years, sometimes leading to an intolerance to prosthesis use $\mathrm{e}^{1,3,6,9,10,12-14}$. The results of this study agree with those of these authors ${ }^{1,3,6,9,10,12-14}$ regarding the fact that, despite the pathogenicity of the microorganisms, their presence does not depend on the type of cleansing solution used given that bacteria persisted the $\mathrm{OP}$ and $\mathrm{AC}$, though in a smaller number. This fact is clearly observed when the results of 
TABLE 1- Cfu counting for aerobic microorganisms, S. aureus and gram negative bacilli on the ocular prosthesis

\begin{tabular}{|c|c|c|c|c|c|c|c|c|c|c|c|c|}
\hline \multirow[b]{2}{*}{ Patient } & \multicolumn{4}{|c|}{ Aerobic microorganisms } & \multirow[b]{2}{*}{$\mathbf{I}$} & \multicolumn{2}{|c|}{ S. aureus } & \multirow[b]{2}{*}{$\mathbf{P}$} & \multicolumn{4}{|c|}{ Gram-negative bacilli } \\
\hline & I & LS & MS & $\mathbf{P}$ & & Ls & MS & & $\mathbf{I}$ & LS & MS & $\mathbf{P}$ \\
\hline 1 & 960 & 160 & 250 & 100 & 0 & 0 & 0 & 0 & 0 & 0 & 0 & 0 \\
\hline 2 & 3000 & 7400 & 3800 & 0 & 1440 & 4800 & 3200 & 0 & 0 & 0 & 0 & 0 \\
\hline 3 & 54000 & 21900 & 1900 & 17100 & 0 & 0 & 0 & 0 & 0 & 0 & 0 & 0 \\
\hline 4 & 12000 & 850 & 3300 & 5900 & 0 & 0 & 0 & 0 & 1120 & 600 & 760 & 4260 \\
\hline 5 & 90000 & 180 & 840 & 100 & 0 & 0 & 0 & 0 & 0 & 0 & 0 & 0 \\
\hline 6 & 72000 & 7300 & 2130 & 5200 & 1800 & 2600 & 3800 & 3400 & 102 & 60 & 180 & 180 \\
\hline 7 & 24000 & 40 & 340 & 80 & 11800 & 20 & 180 & 40 & 0 & 0 & 0 & 0 \\
\hline 8 & 44000 & 10600 & 22000 & 980 & 21000 & 1600 & 6000 & 40 & 0 & 0 & 0 & 0 \\
\hline 9 & 170 & 380 & 20 & 80 & 0 & 0 & 0 & 0 & 0 & 0 & 0 & 0 \\
\hline 10 & 440 & 220 & 590 & 0 & 430 & 60 & 170 & 0 & 0 & 0 & 0 & 0 \\
\hline 11 & 28000 & 58000 & 74000 & 3300 & 15600 & 3800 & 800 & 20 & 0 & 0 & 0 & 0 \\
\hline 12 & 42000 & 66000 & 44000 & 12000 & 26000 & 34400 & 12000 & 2800 & 0 & 0 & 0 & 0 \\
\hline 13 & 38000 & 790 & 1840 & 6000 & 0 & 0 & 0 & 0 & 0 & 0 & 0 & 0 \\
\hline 14 & 28000 & 5000 & 340 & 2800 & 4000 & 1200 & 180 & 1000 & 0 & 0 & 0 & 0 \\
\hline 15 & 3004000 & 4658000 & 402000 & 80 & 179000 & 656400 & 144200 & 0 & 15780 & 31200 & 220 & 0 \\
\hline 16 & 92400 & 6200 & 8600 & 570 & 1600 & 1600 & 980 & 700 & 100 & 960 & 810 & 40 \\
\hline 17 & 578000 & 226000 & 74000 & 910000 & 0 & 0 & 0 & 0 & 0 & 0 & 0 & 0 \\
\hline 18 & 642000 & 56000 & 60000 & 5300 & 125000 & 1400 & 2660 & 20 & 3780 & 5740 & 140 & 760 \\
\hline 19 & 5500 & 420 & 80 & 180 & 0 & 0 & 0 & 0 & 0 & 0 & 0 & 0 \\
\hline 20 & 1810000 & 2132000 & 2476000 & 2962000 & 15700 & 11000 & 1800 & 1800 & 19940 & 13580 & 378000 & 17020 \\
\hline 21 & 14000 & 1400 & 7000 & 2000 & 2600 & 680 & 1200 & 80 & 80 & 40 & 1020 & 60 \\
\hline 22 & 480 & 790 & 500 & 280 & 0 & 0 & 0 & 0 & 0 & 0 & 0 & 0 \\
\hline 23 & 14700 & 720 & 1110 & 3000 & 0 & 0 & 0 & 0 & 0 & 0 & 0 & 0 \\
\hline 24 & 34000 & 590 & 560 & 330 & 520 & 0 & 0 & 0 & 140 & 80 & 60 & 60 \\
\hline
\end{tabular}

I = Initial; LS = Liquid Soap; MS = Complete Multiuse Solution; P = Periogard

TABLE 2- Cfu counting for aerobic microorganisms, S. aureus and gram negative bacilli in the anophthalmic cavity

\begin{tabular}{|c|c|c|c|c|c|c|c|c|c|c|c|c|}
\hline \multirow[b]{2}{*}{ Patient } & \multicolumn{4}{|c|}{ Aerobic microorganisms } & \multirow[b]{2}{*}{ I } & \multicolumn{3}{|c|}{ S. aureus } & \multicolumn{4}{|c|}{ Gram-negative bacilli } \\
\hline & I & LS & MS & $\mathbf{P}$ & & Ls & MS & $\mathbf{P}$ & $\mathbf{I}$ & LS & MS & $\mathbf{P}$ \\
\hline 1 & 460 & 650 & 100 & 120 & 0 & 0 & 0 & 0 & 0 & 0 & 0 & 0 \\
\hline 2 & 7800 & 4100 & 3100 & 0 & 590 & 810 & 800 & 0 & 0 & 0 & 0 & 0 \\
\hline 3 & 668000 & 430000 & 102000 & 132000 & 0 & 0 & 0 & 0 & 0 & 0 & 0 & 0 \\
\hline 4 & 36000 & 4600 & 40000 & 580 & 0 & 0 & 0 & 0 & 2800 & 100 & 240 & 100 \\
\hline 5 & 570 & 430 & 1600 & 710 & 0 & 0 & 0 & 0 & 0 & 0 & 0 & 0 \\
\hline 6 & 86000 & 58000 & 12000 & 11900 & 18600 & 14000 & 2200 & 6600 & 660 & 220 & 100 & 140 \\
\hline 7 & 30000 & 40 & 480 & 700 & 1700 & 20 & 180 & 490 & 0 & 0 & 0 & 0 \\
\hline 8 & 76000 & 46000 & 44000 & 22000 & 22200 & 6000 & 13800 & 140 & 840 & 200 & 140 & 180 \\
\hline 9 & 440 & 470 & 990 & 330 & 0 & 0 & 0 & 0 & 0 & 0 & 0 & 0 \\
\hline 10 & 3400 & 3400 & 610 & 200 & 860 & 1600 & 600 & 120 & 0 & 0 & 0 & 0 \\
\hline 11 & 88000 & 26000 & 8700 & 7700 & 25600 & 8400 & 800 & 660 & 0 & 0 & 0 & 0 \\
\hline 12 & 40000 & 70000 & 24000 & 5300 & 16200 & 26000 & 5600 & 1200 & 0 & 0 & 0 & 0 \\
\hline 13 & 1258000 & 3200 & 35900 & 42000 & 0 & 0 & 0 & 0 & 0 & 0 & 0 & 0 \\
\hline 14 & 16500 & 4500 & 560 & 180 & 6200 & 600 & 490 & 260 & 0 & 0 & 0 & 0 \\
\hline 15 & 1262000 & 212000 & 22000 & 1800 & 107800 & 119800 & 17200 & 0 & 11140 & 140 & 620 & 0 \\
\hline 16 & 102000 & 2810 & 9300 & 360 & 470 & 160 & 280 & 20 & 220 & 60 & 40 & 80 \\
\hline 17 & 1742000 & 1164000 & 566000 & 3360000 & 0 & 0 & 0 & 0 & 120 & 80 & 40 & 20 \\
\hline 18 & 28000 & 3700 & 1600 & 6000 & 6200 & 370 & 260 & 20 & 300 & 40 & 100 & 220 \\
\hline 19 & 10800 & 40 & 380 & 280 & 0 & 0 & 0 & 0 & 0 & 0 & 0 & 0 \\
\hline 20 & 3182000 & 4178000 & 4024000 & 3266000 & 18680 & 21200 & 24600 & 19000 & 26500 & 31130 & 87800 & 20500 \\
\hline 21 & 5600 & 3900 & 44000 & 18000 & 31800 & 2800 & 25800 & 340 & 2040 & 920 & 1040 & 120 \\
\hline 22 & 20000 & 9800 & 36000 & 18000 & 580 & 40 & 20 & 20 & 0 & 0 & 0 & 0 \\
\hline 23 & 32000 & 1800 & 1890 & 9700 & 0 & 0 & 0 & 0 & 2040 & 520 & 250 & 620 \\
\hline 24 & 42000 & 610 & 500 & 260 & 850 & 60 & 0 & 0 & 1180 & 20 & 40 & 40 \\
\hline
\end{tabular}

I = Initial; LS = Liquid Soap; MS = Complete Multiuse Solution; P = Periogard 
the cleansing solutions (neutral liquid soap, multiuse solution and Periogard) were compared to the initial condition (no cleansing).

Few studies have addressee OP cleansing methods, the most common being the use of water and soap ${ }^{11,12}$. Removal of the OP, use of solutions indicated for cleansing of contact lenses and periodical examination by a health professional have also been recommended to ensure the proper cleansing and assess the integrity of tissues that cover the $\mathrm{AC}$ and the need for changing the prosthesis ${ }^{4,6,8,13}$.

The findings of the present study showed that the use of a contact lens multiuse solution for cleansing of the OP yielded a decrease in the number of microorganisms on both the prosthesis and the anophthalmic cavity.

The use $0.12 \%$ chlorhexidine is widely widespread for chemical biofilm control because of its bacteriostatic action against gram-positive and gram-negative microorganisms. Periogard was used in this study because it is a readily available product that does not offer risks to patients' health. After use of Periogard, the biofilm presented a smaller number of colony forming units in comparison to the initial condition. These results suggest that, although it does not differ significantly from the other solutions, Periogard had an evident bacteriostatic effect, given that, after its use, bacterial growth in the biofilm or AC was less intense compared to the use of the other solutions. In some cases, no bacterial growth was observed.

There are no studies referring to the correlation between the presence of microorganisms in the $\mathrm{OP}$ or $\mathrm{AC}$ and cleansing solutions that could serve as a parameter to the

TABLE 3- Results of the analysis of variance for the presence of aerobic microorganisms

(H0) Probability $\quad$ Anophthalmic Cavity Ocular Prosthesis

\begin{tabular}{lll}
\hline Among Patients & $0.0000 \%$ & $0.0000 \%{ }^{*}$ \\
Among Solutions & $0.0009 \%$ & $0.0009 \%$ \\
\hline
\end{tabular}

*Statistically significant at $1 \%$ level

TABLE 4- Results of the Friedman's test for the presence of $S$. aureus and gram-negative bacilli

\begin{tabular}{lllll} 
Two-by-two comparisons & \multicolumn{2}{c}{ S. aureus } & \multicolumn{2}{c}{ Gram-negative bacillix } \\
& AC & OP & AC & OP \\
\hline IxLS & $\mathrm{ns}$ & $\mathrm{ns}$ & $1 \%$ & $\mathrm{~ns}$ \\
IxMS & $1 \%$ & $5 \%$ & $1 \%$ & $\mathrm{~ns}$ \\
IxP & $0.1 \%$ & $0.1 \%$ & $1 \%$ & $\mathrm{~ns}$ \\
LSxMS & $\mathrm{ns}$ & $\mathrm{ns}$ & $\mathrm{ns}$ & $\mathrm{ns}$ \\
LS X P & $0.1 \%$ & $1 \%$ & $\mathrm{~ns}$ & $\mathrm{~ns}$
\end{tabular}

Ns = non-significant. I = Initial; LS = Liquid Soap; MS = Complete Multiuse Solution; P = Periogard. AC= Anophthalmic Cavity; $\mathrm{OP}=$ Ocular Prosthesis

TABLE 5- Results of Spearman's correlation test for the presence of aerobic microorganisms, S. aureus and gram-negative bacilli

Two-by-two comparisons

Aerobic microorganisms

\section{Ho Probability}

S. aureus

Gram-negative bacilli

\begin{tabular}{|c|c|c|c|}
\hline IACXOP & $0.0000 \%$ & $0.0000 \%$ & $0.0000 \%$ \\
\hline LS ACXOP & $0.2800 \%$ & $0.0000 \%$ & $0.0400 \%$ \\
\hline MS ACXOP & $0.0200 \%$ & $0.0000 \%$ & $0.0000 \%$ \\
\hline PACXOP & $0.0000 \%$ & $0.0000 \%$ & $0.0000 \%$ \\
\hline
\end{tabular}

I = Initial; LS = Liquid Soap; MS = Complete Multiuse Solution; P = Periogard; AC = Anophthalmic cavity; OP= Ocular prosthesis 
outcomes of the present study. Portellinha, et al. ${ }^{13}$ (1984) correlated the presence of secretion with the time of use and the frequency of prosthesis cleansing and found that the bacterial colonization in the $\mathrm{AC}$ and the frequency of $\mathrm{OP}$ cleansing had no statistically significant correlation. Campos $^{2}$ (1994) did not find a positive correlation between the time of use of OP and the presence of microorganisms.

In the present investigation, a positive correlation was found between the microorganisms on the prosthesis/ cavities and the four types of treatment (no cleansing and three cleansing solutions), which indicates that the decrease of OP contamination would lead to a decrease of AC contamination. Therefore, OP cleansing is essential to reduce contamination of AC, improving the comfort of OP wearers and consequently their life quality.

\section{CONCLUSIONS}

1. Aerobic microorganisms and gram-negative bacilli were found in OP biofilm as well as in the AC before and after the use of the studied cleansing solutions.

2. All solutions were similarly effective in decreasing the number of aerobic microorganisms in the OP and AC compared to the initial condition;

3. Periogard and MS decreased of the number of $S$.

TABLE 6- Comparison of the number of cfu of aerobic microorganisms, S. aureus and gram-negative bacilli in the OP biofilm and $\mathrm{AC}$ before and after use of the cleansing solutions

\begin{tabular}{|c|c|c|c|c|c|c|}
\hline \multirow[t]{2}{*}{ Two-by-two comparisons } & \multicolumn{2}{|c|}{ Aerobic microorganisms } & \multicolumn{2}{|c|}{ S. aureus } & \multicolumn{2}{|c|}{ Gram-negative bacilli } \\
\hline & OP & AC & OP & AC & OP & $A C$ \\
\hline I & $24+$ & $24+$ & $\begin{array}{l}14+ \\
10-\end{array}$ & $\begin{array}{l}15+ \\
9-\end{array}$ & $\begin{array}{l}8+ \\
16\end{array}$ & $\begin{array}{l}11+ \\
13-\end{array}$ \\
\hline IXLS & $\begin{array}{l}17 \downarrow \\
7 \uparrow\end{array}$ & $\begin{array}{l}19 \downarrow \\
4 \uparrow \\
1=\end{array}$ & $\begin{array}{l}8 \downarrow \\
4 \uparrow \\
1= \\
11-\end{array}$ & $\begin{array}{l}10 \downarrow \\
5 \uparrow \\
9-\end{array}$ & $\begin{array}{l}5 \downarrow \\
3 \uparrow \\
16-\end{array}$ & $\begin{array}{l}10 \downarrow \\
1 \uparrow \\
13-\end{array}$ \\
\hline IXMS & $\begin{array}{l}17 \downarrow \\
7 \uparrow\end{array}$ & $\begin{array}{l}19 \downarrow \\
5 \uparrow\end{array}$ & $\begin{array}{l}11 \downarrow \\
2 \uparrow \\
11-\end{array}$ & $\begin{array}{l}12 \downarrow \\
2 \uparrow \\
10-\end{array}$ & $\begin{array}{l}4 \downarrow \\
4 \uparrow \\
16-\end{array}$ & $\begin{array}{l}10 \downarrow \\
1 \uparrow \\
13-\end{array}$ \\
\hline LSXMS & $\begin{array}{l}11 \downarrow \\
13 \uparrow\end{array}$ & $\begin{array}{l}14 \downarrow \\
10 \uparrow\end{array}$ & $\begin{array}{l}7 \downarrow \\
6 \uparrow \\
11-\end{array}$ & $\begin{array}{l}9 \downarrow \\
5 \uparrow \\
10-\end{array}$ & $\begin{array}{l}4 \downarrow \\
4 \uparrow \\
16-\end{array}$ & $\begin{array}{l}5 \downarrow \\
6 \uparrow \\
13-\end{array}$ \\
\hline$P \times I$ & $\begin{array}{l}20 \downarrow \\
3 \uparrow \\
1-\end{array}$ & $\begin{array}{l}20 \downarrow \\
2 \uparrow \\
2-\end{array}$ & $\begin{array}{l}9 \downarrow \\
1 \uparrow \\
14-\end{array}$ & $\begin{array}{l}11 \downarrow \\
1 \uparrow \\
12-\end{array}$ & $\begin{array}{l}5 \downarrow \\
2 \uparrow \\
17-\end{array}$ & $\begin{array}{l}10 \downarrow \\
14-\end{array}$ \\
\hline PXLS & $\begin{array}{l}16 \downarrow \\
6 \uparrow \\
2- \\
14-\end{array}$ & $\begin{array}{l}14 \downarrow \\
9 \uparrow \\
1-\end{array}$ & $\begin{array}{l}8 \downarrow \\
2 \uparrow \\
14-\end{array}$ & $\begin{array}{l}12 \downarrow \\
12-\end{array}$ & $\begin{array}{l}3 \downarrow \\
4 \uparrow \\
17-\end{array}$ & $\begin{array}{l}5 \downarrow \\
4 \uparrow \\
1=\end{array}$ \\
\hline PXMS & $\begin{array}{l}14 \downarrow \\
8 \uparrow \\
2-\end{array}$ & $\begin{array}{l}16 \downarrow \\
7 \uparrow \\
1-\end{array}$ & $\begin{array}{l}8 \downarrow \\
1 \uparrow \\
1= \\
14-\end{array}$ & $\begin{array}{l}9 \downarrow \\
2 \uparrow \\
1= \\
12-\end{array}$ & $\begin{array}{l}4 \downarrow \\
2 \uparrow \\
1= \\
17\end{array}$ & $\begin{array}{l}4 \downarrow \\
5 \uparrow \\
5 \uparrow \\
14-\end{array}$ \\
\hline
\end{tabular}

$\mathrm{I}=$ Initial; LS = Liquid Soap; MS = Complete Multiuse Solution; P = Periogard. AC= Anophthalmic Cavity; OP= Ocular Prosthesis. (?) decrease in the number of microorganisms / (?) Increase in the number of microorganisms. (+) positive culture; (-) negative culture; (=) unchanged number of microorganisms 
aureus in the $\mathrm{OP}$ and $\mathrm{AC}$ compared to the initial condition;

4. There was no significant difference between the initial condition and the studied solutions regarding the presence of gram-negative bacilli in the OP biofilm; for AC, the three solutions were yielded better outcomes than the initial condition.

5. Under the tested conditions, there was a positive correlation for the presence of aerobic microorganisms, $S$. aureus and gram-negative bacilli.

\section{REFERENCES}

1- Akman A, Irkec M, Orhan M, Erdener U. Effect of lodoxamide on tear leukotriene levels in giant papillary conjunctivitis associated with ocular prosthesis. Ocul Immunol Inflamm. 1998;6(3):179-84.

2- Campos MS, Campos e Silva LQ, Rehder Jr, Lee MB, O’brien T, McDonnell PJ. Anaerobic flora of the conjunctival sac in patients with AIDS and with anophthalmia compared with normal eyes. Acta Ophthalmol (Copenh). 1994;72(2):241-5

3- Campos MSQ. Microbiota bacteriana anaeróbica do saco conjuntival humano normal, de cavidades anoftálmicas de usuários de prótese ocular e de pacientes aidéticos [tese]. São Paulo (SP): Escola Paulista de Medicina, Universidade Federal de São Paulo; 1990.

4- Goldfarb HJ, Turtz AI. A detergent- lubricant solution for artificial eyes. Am J Ophthalmol. 1966;16(6):1502-5.

5- Ito Y, Costa A, Barachini O. Emprego da gema de ovo no isolamento de Staphylococus. Ann Microbiol. 1979;16:189-92.

6- Kara José N, Prado J Júnior, Sampaio M W. Intolerância ao uso de prótese ocular pelo desenvolvimento de conjuntivite papilar gigante. Rev Bras Oftalmol. 1980;39(1):51-3.

7- Kohlhaas M, Schulz D. The complex facial prosthesis: the value of bone-anchored maxillofacial prostheses in the treatment of extensive loss of facial tissue. Rev Stomatol Chir Maxillofac. $2001 ; 102(5): 261-5$

8- Maimone N, Maimone AL. Avaliação de um novo produto na desinfecção do tonômetro de aplanação de Goldmann. Arq Bras Oftalmol. 2001;64(6):545-9.

9- Morris R, Camesasca FI, Byrne J, John G. Postoperative endophthalmitis resulting from prosthesis contamination in a monocular patient. Am J Ophthalmol. 1993;116(3):346-9.

10 - Neves ACC. Avaliação clínica e microbiológica da secreção conjuntival em usuários de prótese ocular em resina acrílica [tese]. São José dos Campos (SP): Faculdade de Odontologia de São José dos Campos, Universidade Estadual Paulista "Júlio de Mesquita Filho"; 2000 .

11 - Nuti A Sobrinho, Lima EG, Mattos MGC, Watanabe S. A study of ocular prostheses. I. Manufacture and indications for use. Rev Fac Odontol Ribeirão Preto. 1986;23(2):135-43

12 - Nuti A Sobrinho. Contribuição ao estudo de microorganismos encontrados em prótese ocular de resina acrílica e em cavidade anoftálmica [tese]. Ribeirão Preto (SP): Faculdade de Odontologia de Ribeirão Preto, Universidade de São Paulo; 1986.

13 - Portellinha WM, Belfort JR, Cai S, Novo NF. Estudo clínico microbiológico, citológico e de função lacrimal em pacientes com cavidade anoftálmica e uso de prótese ocular de acrílico. Arq Bras Oftalmol. 1984;47(4):159-63.
14-Sarac O, Erdener U, Irkec M, Gungen Y. Tear eotaxin levels in giant papillary conjunctivitis associated with OP. Ocul Immunol Inflamm. 2003;11(3):223-30.

15- Westergren G, Krasse B. Evaluation of a micromethod for determination of Streptococcus mutans and Lactobacillus infection. J Clin Microbiol. 1979;7(1):82-3. 